\title{
Transcriptional Regulation of Thrombin-Induced Endothelial VEGF Induction and Proangiogenic Response
}

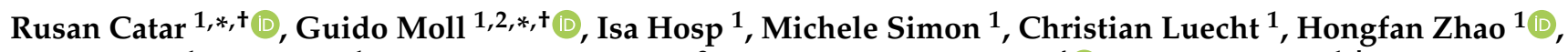 \\ Dashan $\mathrm{Wu}^{1}{ }^{1}$, Lei Chen ${ }^{1}$, Julian Kamhieh-Milz ${ }^{3}$, Katarzyna Korybalska ${ }^{4}{ }^{\oplus}$, Daniel Zickler ${ }^{1,+}$ \\ and Janusz Witowski ${ }^{1,4,+}$ (i)
}

1 Department of Nephrology and Internal Intensive Care Medicine, Charité-Universitätsmedizin Berlin, Corporate Member of Freie Universität Berlin and Humboldt-Universität zu Berlin, 10117 Berlin, Germany; isa@lutzschramm.de (I.H.); michele.simon@charite.de (M.S.); christian.luecht@charite.de (C.L.); hongfan.zhao@charite.de (H.Z.); Dashan.wu@charite.de (D.W.); lei.chen1991@gmail.com (L.C.); daniel.zickler@charite.de (D.Z.); jwitow@ump.edu.pl (J.W.)

2 BIH Center for Regenerative Therapies (BCRT) and Berlin-Brandenburg School of Regenerative Therapies (BSRT), Berlin Institute of Health (BIH), Charité-Universitätsmedizin Berlin, 10117 Berlin, Germany

3 Institute of Transfusion Medicine, Charité-Universitätsmedizin Berlin, 10117 Berlin, Germany; julian.milz@charite.de

4 Department of Pathophysiology, Poznan University of Medical Sciences, 60-806 Poznan, Poland; koryb@ump.edu.pl

* Correspondence: rusan.catar@charite.de (R.C.); guido.moll@charite.de (G.M.)

+ These authors contributed equally to this work.

check for updates

Citation: Catar, R.; Moll, G.; Hosp, I.; Simon, M.; Luecht, C.; Zhao, H.; Wu, D.; Chen, L.; Kamhieh-Milz, J.; Korybalska, K.; et al. Transcriptional Regulation of Thrombin-Induced Endothelial VEGF Induction and Proangiogenic Response. Cells 2021 10, 910. https://doi.org/10.3390/ cells10040910

Academic Editor: Alessandro Poggi

Received: 16 March 2021

Accepted: 11 April 2021

Published: 15 April 2021

Publisher's Note: MDPI stays neutral with regard to jurisdictional claims in published maps and institutional affiliations.

Copyright: (c) 2021 by the authors. Licensee MDPI, Basel, Switzerland. This article is an open access article distributed under the terms and conditions of the Creative Commons Attribution (CC BY) license (https:/ / creativecommons.org/licenses/by/ $4.0 /)$.

\begin{abstract}
Thrombin, the ligand of the protease-activated receptor 1 (PAR1), is a well-known stimulator of proangiogenic responses in vascular endothelial cells (ECs), which are mediated through the induction of vascular endothelial growth factor (VEGF). However, the transcriptional events underlying this thrombin-induced VEGF induction and angiogenic response are less well understood at present. As reported here, we conducted detailed promotor activation and signal transduction pathway studies in human microvascular ECs, to decipher the transcription factors and the intracellular signaling events underlying the thrombin and PAR-1-induced endothelial VEGF induction. We found that c-FOS is a key transcription factor controlling thrombin-induced EC VEGF synthesis and angiogenesis. Upon the binding and internalization of its G-protein-coupled PAR-1 receptor, thrombin triggers ERK1/2 signaling and activation of the nuclear AP-1/c-FOS transcription factor complex, which then leads to VEGF transcription, extracellular secretion, and concomitant proangiogenic responses of ECs. In conclusion, exposure of human microvascular ECs to thrombin triggers signaling through the PAR-1-ERK1/2-AP-1/c-FOS axis to control VEGF gene transcription and VEGF-induced angiogenesis. These observations offer a greater understanding of endothelial responses to thromboinflammation, which may help to interpret the results of clinical trials tackling the conditions associated with endothelial injury and thrombosis.
\end{abstract}

Keywords: cardiovascular diseases (CVD); endothelial cells (ECs); innate immune response; thromboinflammation; thrombin; protease-activated receptor 1 (PAR-1); activator protein 1 (AP-1) transcription factor complex; vascular endothelial growth factor (VEGF); angiogenesis

\section{Introduction}

Cardiovascular diseases (CVDs) are a leading cause of death worldwide [1,2]. Endothelial cell (EC) dysfunction is a critical stage in the development of many CVDs [3]. The endothelium provides a thromboresistant inner lining of the vascular wall, thus preventing uncontrolled clot formation [3,4]. Several acute and chronic pathologies can promote EC dysfunction and predispose the interface to a prothrombotic state $[5,6]$. The inflammation that is associated with these conditions can promote EC activation and expression of highly 
procoagulant tissue factor (TF/CD142) [7-9], thereby promoting thromboinflammation and the generation of thrombin (Figure 1A). The generation of thrombin in the vicinity of ECs leads to endothelial activation and the release of vascular endothelial growth factor (VEGF) to stimulate endothelial repair.

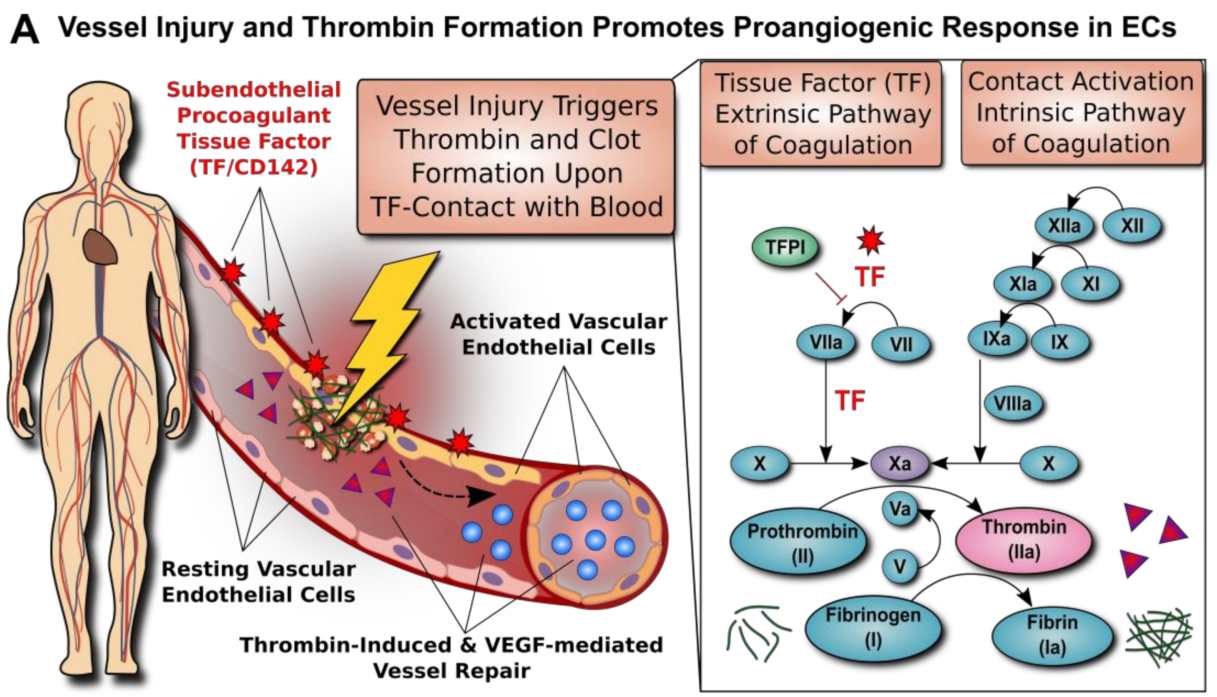

B Molecular Mechanisms Underlying Endothelial Angiogenic Response to Thrombin

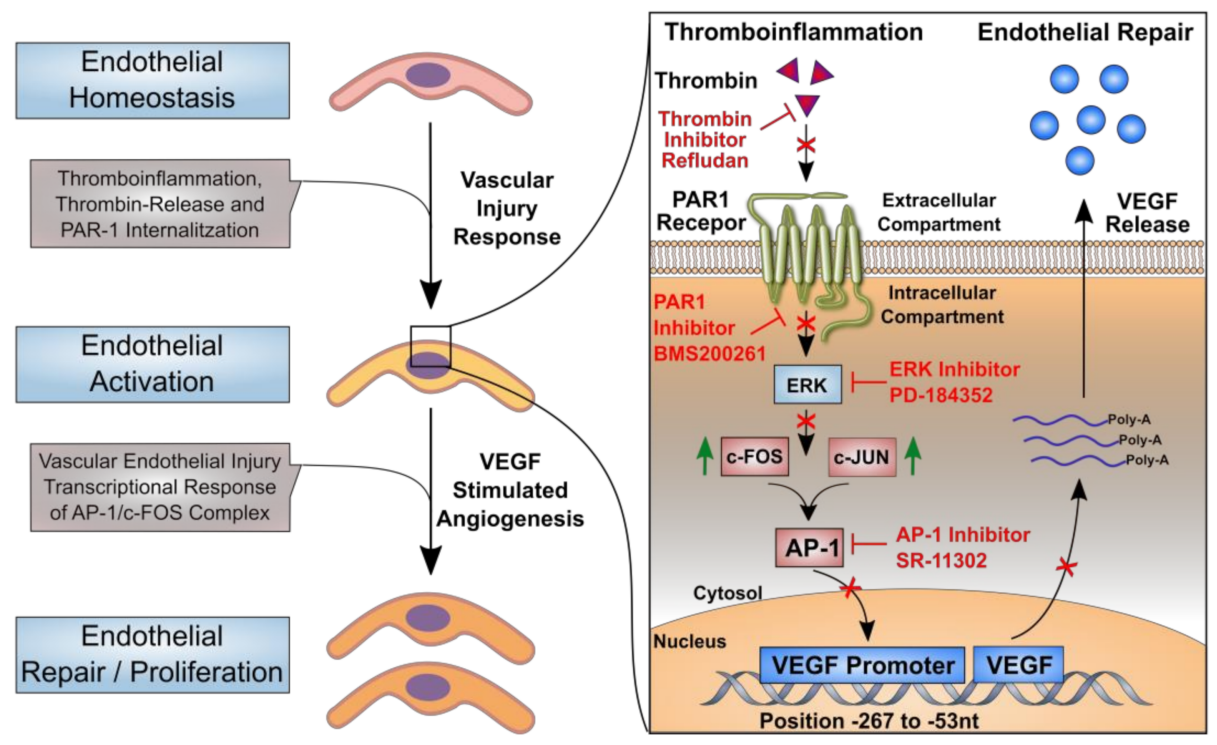

Figure 1. Transcriptional regulation of thrombin-induced endothelial cell VEGF induction. (A) Vessel injury and thrombin formation promote a proangiogenic response in ECs. While resting vascular ECs form a protective anticoagulant lining that prevents uncontrolled blood activation at the blood-endothelial interface [8], different types of pathological conditions can promote activation of vascular ECs, leading to thrombin and clot formation. Thromboinflammation may be triggered upon disruption of the protective endothelial interface, thereby allowing the detrimental contact of blood with subendothelial highly procoagulant tissue factor (TF/CD142), which can induce the extrinsic TF pathway of coagulation. In addition, the intrinsic contact activation pathway of coagulation may be activated through multiple triggers. Activation of either coagulation pathway leads to conversion of prothrombin to thrombin and fibrinogen to fibrin, with thrombin being able to stimulate EC activation and release of VEGF with concomitant EC proliferation and repair. (B) Molecular mechanisms underlying endothelial angiogenic response to thrombin. ECs can be activated by various stimuli (e.g., vascular injury, thromboinflammation, and thrombin release), which can promote EC proliferation and repair (e.g., VEGF-stimulated angiogenesis). We here identified that these events are mediated through a signaling cascade involving PAR-1, ERK, and AP-1 signaling, with concomitant VEGF promoter engagement (Position -267 to -53 nucleotides from the VEGF gene), VEGF mRNA synthesis, and VEGF protein secretion. 
Under physiological conditions, thrombin acts on ECs through protease-activated receptor-1 (PAR-1) to counteract excessive thrombotic responses. Thrombin can stimulate protective responses in ECs to release nitric oxide, prostacyclin, and tissue-type plasminogen activator, which cause vasodilation, platelet inhibition, and fibrinolysis, respectively $[4,10]$. Thrombin also contributes to wound healing by promoting angiogenesis, vascular remodeling, and antimicrobial activity [11-13]. These thrombin activities are mediated through intricate transcriptional networks, whose operations have only been partially deciphered so far [3,4]. The effect of thrombin on dysfunctional endothelium is less well understood. Presumably, during the induction and progression of endothelial dysfunction, thrombin may trigger aberrant responses that cause further deterioration, thus adversely affecting vascular tone, permeability, and angiogenesis.

Angiogenesis can be modulated by thrombin through different mechanisms [14], including direct effects on the endothelium, such as potent stimulation of EC proliferation and migration (Figure 1B, left panel) [15-17], but also through indirect mechanisms, such as upregulation of the receptors responsive to angiogenic stimuli and increased expression of adhesion receptors and integrins for EC migration and survival [18-20]. Thrombin can amplify the effects of VEGF by increasing the expression of functional VEGF receptors on ECs [20,21]. Increased expression of the VEGF gene in response to thrombin was detected in several cell types, including platelets [22-24], fibroblasts [22], astrocytes [24], retinal pigment epithelial cells [25-27], vascular smooth muscle cells [28,29], adipocytes [30], and mesothelial cells [31], as well as several malignant cell types [22,32-35]. A first study examining this aspect in human ECs documented thrombin-induced VEGF expression in human umbilical vein ECs and suggested the involvement of hypoxia-induced transcription factor 1 alpha [36]. Intriguingly, thrombin is known to induce many transcription factors in ECs [11], and the VEGF promoter contains numerous putative binding sites for transcription factors [37].

The connection between thrombin and VEGF has received renewed interest during the COVID-19 pandemic, due to the pronounced coagulopathy in severely affected patients [38], which develop acute respiratory distress syndrome (ARDS), vascular leakage and altered angiogenesis [39]. VEGF is a key mediator of pathological angiogenesis [40] and it has also long been suspected to contribute to the pathogenesis of ARDS [41]. To date, a detailed analysis of the transcriptional regulation of VEGF expression by thrombin in ECs and its link to endothelial angiogenesis has been lacking. We here show that the activator protein 1 (AP-1)/c-FOS transcription complex is a key regulator of the VEGF-mediated angiogenic response of ECs to thrombin (Figure 1B, right panel).

\section{Materials and Methods}

\subsection{Materials}

Unless stated otherwise, all chemicals were from Sigma-Aldrich (St Louis, MO, USA), and all culture plastics were from Becton Dickinson (Falcon; Franklin Lakes, NJ, USA). Cell culture media and buffers were from Thermo Fisher (Waltham, MA, USA) and fetal calf serum (FCS) from Invitrogen (Darmstadt, Germany). The antibody characteristics are given in the Supplementary Materials (Tables S1 and S2). Thrombin used was $\alpha$-thrombin from human plasma with concentrations reported in NIH units of activity.

\subsection{Endothelial Cell Culture, Tube Formation Assay, and VEGF Protein and Gene Expression}

Human microvascular endothelial cells (HMECs, catalogue no. CRL-3243) were purchased from ATCC ${ }^{\circledR}$ (Manassas, VA, USA) and used at passage 2-6. The EC tube formation assay was conducted as outline previously [42,43]. Briefly, Matrigel (Corning, Tewksbury, MA, USA) was poured onto a $96-w e l l ~ p l a t e ~(50 \mu \mathrm{L} /$ well $)$ and solidified at $37^{\circ} \mathrm{C}$ for $30 \mathrm{~min}$. HMECs were suspended in MCDB131 culture medium supplemented with penicillin, streptomycin, glutamine (all at standard cell culture doses), hydrocortisone (10 $\mathrm{nM})$, and $0.5 \%$ FCS, and then seeded onto the Matrigel $\left(2 \times 10^{4}\right.$ cells/well $)$ and stimulated as specified in figure legends. The formation of capillary tube networks was evaluated after $16 \mathrm{~h}$ 
and photographed under the microscope (Zeiss Axiovert 40 CFL Oberkochen, Germany), and three randomly selected fields were analyzed for different parameters of endothelial tube network formation (e.g., the number of meshes) using Image 1.43 software (National Institutes of Health, Bethesda, MD, USA). VEGF protein was measured using a DuoSet Immunoassay Kit (R\&D Systems, Minneapolis, MN, USA) [44]. Expression of the VEGF gene (and $\beta 2 M$ as a housekeeping gene) was assessed with reverse transcription and quantitative PCR (RT-qPCR), as described previously [42,45-48].

\subsection{DNA Construct, Transient Transfection, and Analysis of the VEGF Promoter}

The DNA constructs of predefined VEGF promoter fragments were provided by Dr. A. Scholz [49] and checked for correct length of promoter segments by restriction digest. For transient transfection studies, cells were seeded into 6-well culture plates and transfections performed at $70-80 \%$ cell confluence in the absence of serum using the TurboFect ${ }^{\mathrm{TM}}$ transfection reagent (Thermo Fisher). The HMECs were transfected with the VEGF reporter plasmids and the reference plasmids and assayed with the dual-luciferase reporter assay system (Promega) [35]. The human VEGF promoter region located at -268 to -51 nt (GenBank NT_007592.15) was analyzed with the PROMO virtual laboratory for the presence and location of potential transcription factor binding sites: http:/ /alggen.lsi.upc. es/cgi-bin/promo_v3/promo/promoinit.cgi?dirDB=TF_8.3, accessed on 11 April 2021.

\subsection{Nuclear Extracts and Electrophoretic Mobility Shift Assay}

Nuclear extracts were prepared using the NE-PER Nuclear and Cytoplasmic Extraction Kit and oligonucleotide probes labeled with Biotin 3' End DNA Labeling Kit (all Thermo Fisher). For the electrophoretic mobility shift assay (EMSA) [42], the following probes were used (corresponding region of the VEGF promoter given in brackets, Figure S1D): c-FOS 5'-CTGAGCGTCCGCAGAGCCCGGGCC-3' (-131 to -154) and c-JUN $5^{\prime}$-GTAATTTTCAGGCTGTGAACCTTG-3' (-205 to -228). Each binding mixture $(20 \mu \mathrm{L})$ contained $5 \mu \mathrm{g}$ nuclear extract, $20 \mathrm{fmol}$ labeled double-stranded probe, $1 \mu \mathrm{g}$ poly-dI/dC, and $2 \mu \mathrm{L} 10 \times$ buffer and was incubated at room temperature for $30 \mathrm{~min}$. Protein-DNA complexes were analyzed by electrophoresis in 6\% nondenaturing polyacrylamide gels and visualized with LightShift Chemiluminescent EMSA Kit (Thermo Fisher).

\subsection{Western Blotting Assays and Flow Cytometry on PAR-1 Expression and Internalization}

The cell extracts were prepared as described [48], electrophoresed on sodium dodecyl sulfate-polyacrylamide gels, and Western blotted using antibodies against c-FOS and c-JUN (Santa Cruz Biotechnology), pERK-1/2, and $\beta$-actin (Cell Signaling Technology, Frankfurt, Germany), and appropriate secondary peroxidase-conjugated IgG (Dianova, Hamburg, Germany). The bands obtained were analyzed using the Enhanced Chemiluminescence Detection System (Thermo Scientific) and ImageJ 1.43 software. PAR1 receptor expression and cleavage was assessed with flow cytometry (FACS Aria; Becton Dickinson). Activation of PAR-1 was monitored with the SPAN12 monoclonal antibody detecting a PAR-1 epitope that only exists in the uncleaved receptor, with loss of SPAN12 staining pointing to PAR-1 activation [50]. All experimental steps were performed at $4{ }^{\circ} \mathrm{C}$ to prevent unspecific PAR-1 activation and internalization. HMECs were diluted (3:7) in PBS and incubated for $10 \mathrm{~min}$ with either SPAN12 antibody or a buffer, and then fixed with 1\% paraformaldehyde and analyzed with flow cytometry.

\subsection{Statistics}

Statistical analysis was performed using GraphPad Prism 6.05 software (GraphPad Software). The data were analyzed with the t-test or repeated measures analysis of variance. Results were expressed as means \pm SEM. Differences with a $p$ value $<0.05$ were considered significant. 


\section{Results}

The study background and a summary of the molecular mechanisms identified in this study can be found in Figure 1. In brief, vessel injury and thrombin formation are known to promote proangiogenic responses in ECs. We here elucidate the detailed molecular mechanisms underlying the EC angiogenic response to thrombin.

\subsection{Dose-Response Effect of Thrombin on EC Angiogenesis and VEGF Production}

In prior studies, we employed in vitro endothelial tube formation assays to study angiogenic properties of ECs and mesenchymal stromal cells (MSCs) [42,43], and a similar setup was chosen in this study. Exposure of HMECs to thrombin concentrations of $0.1 \mathrm{U} / \mathrm{mL}$ resulted in a $43 \%$ increase in EC network formation $(p<0.05$; Figure $2 \mathrm{~A})$. Higher thrombin concentrations did not produce such an effect $(1 \mathrm{U} / \mathrm{mL})$ or even impaired $(5 \mathrm{U} / \mathrm{mL})$ endothelial tube formation. The dose of $0.1 \mathrm{U} / \mathrm{mL}$ was chosen for further studies, which is in a similar range as measured under physiological conditions [46,51]. Since VEGF is a main regulator of endothelial angiogenesis, we examined the effect of thrombin on VEGF production by ECs. Indeed, the effect of thrombin on VEGF secretion mirrored that on EC angiogenesis. Exposure of HMECs to thrombin at a concentration of $0.1 \mathrm{U} / \mathrm{mL}$, but not at higher doses, increased VEGF production by more than 2-fold $(p<0.001$; Figure 2B). This effect became most apparent after $12 \mathrm{~h}$ of stimulation $(p<0.01$, more than 2-fold increase; Figure 2C) and was preceded by an increase in VEGF mRNA expression, which already peaked at $1 \mathrm{~h}$ post stimulation $(p<0.05$; Figure 2D).

A
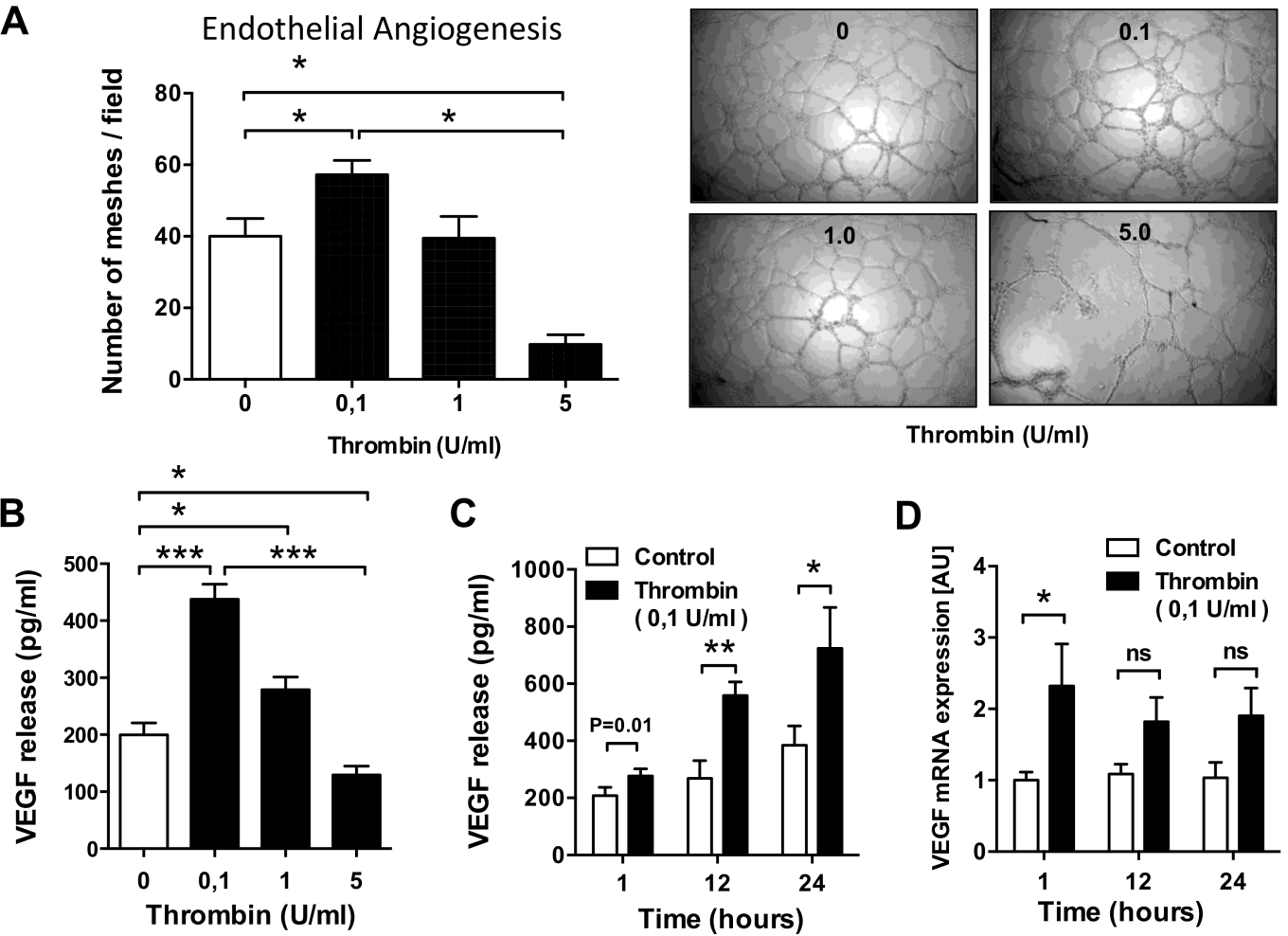

Figure 2. Effect of thrombin on microvascular EC angiogenesis and VEGF production. (A) Human microvascular endothelial cells (HMECs) were stimulated with thrombin at the indicated doses $(0.1,1.0$, and $5.0 \mathrm{U} / \mathrm{mL}$ ), and EC tube formation was assessed after $16 \mathrm{~h}$, with data expressed as the average number of meshes per field $(n=4)$ and representative figures shown to the right. (B-D) HMECs were cultured in the presence or absence of thrombin $(n=8)$ and assessed for dose- $(0.1,1.0$, and $5.0 \mathrm{U} / \mathrm{mL}$ ) and time-dependent $(6,12$, and $24 \mathrm{~h}$ ) VEGF secretion (B,C) and VEGF mRNA levels (C). The exposure time in (A) was $24 \mathrm{~h}$, while the dose of thrombin in (C,D) was $0.1 \mathrm{U} / \mathrm{mL}$. ANOVA mean +/ - SEM with * $p<0.05,{ }^{* *} p<0.01$, and ${ }^{* * *} p<0.001$. 


\subsection{Effect of Thrombin on the VEGF Promoter Activity in Microvascular Endothelial Cells}

To investigate how thrombin affects the activity of the VEGF gene promoter, we employed a set of established assays $[43,45,48]$. The HMECs were first transiently transfected with VEGF luciferase reporter gene constructs and stimulated with thrombin $(0.1 \mathrm{U} / \mathrm{mL})$. This resulted in a significant increase in the full-length VEGF promoter activity $(p<0.01$; Figure 3A). To identify VEGF promoter regions responsive to thrombin, progressive deletions of the VEGF promoter were performed (Figure 3B). Truncation of the promoter region spanning positions -267 to -53 abolished the ability of the VEGF promoter to respond to thrombin, suggesting that the region contained regulatory elements essential for the VEGF promoter activity. The in silico analysis pointed to the presence of high-affinity binding sites for the transcription factor c-FOS. To determine whether c-FOS mediated the effect of thrombin toward the VEGF promoter, an electrophoretic mobility shift assay (EMSA) was performed using a biotin-labeled consensus oligonucleotide for c-FOS or c-JUN binding that corresponded to positions -131 to -154 or -205 to -228 of the VEGF promoter (Figure 3C). This experiment demonstrated that nuclear extracts from cells stimulated with thrombin formed a DNA-protein complex with the c-FOS-specific oligonucleotide more efficiently than with the c-JUN oligonucleotide ( $p<0.001$ vs. $p<0.05)$. To verify the specificity of c-FOS and c-JUN binding, EMSA was performed with a 100-fold molar excess of unlabeled oligonucleotide. This competition assay resulted in a loss of c-FOS and c-JUN-DNA complex. In contrast, EMSA with a specific anti-c-FOS antibody led to a supershift of DNA-protein complex, which was much less profound for anti-c-JUN antibody ( $p<0.001 ; 5$ times weaker signal).

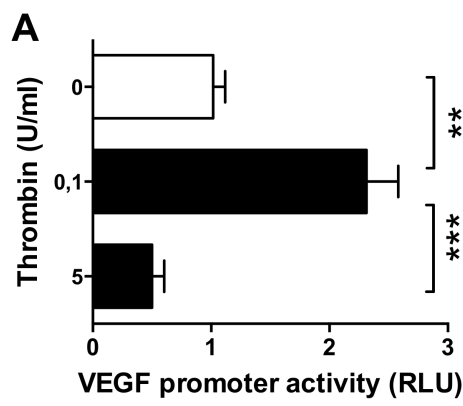

B

C
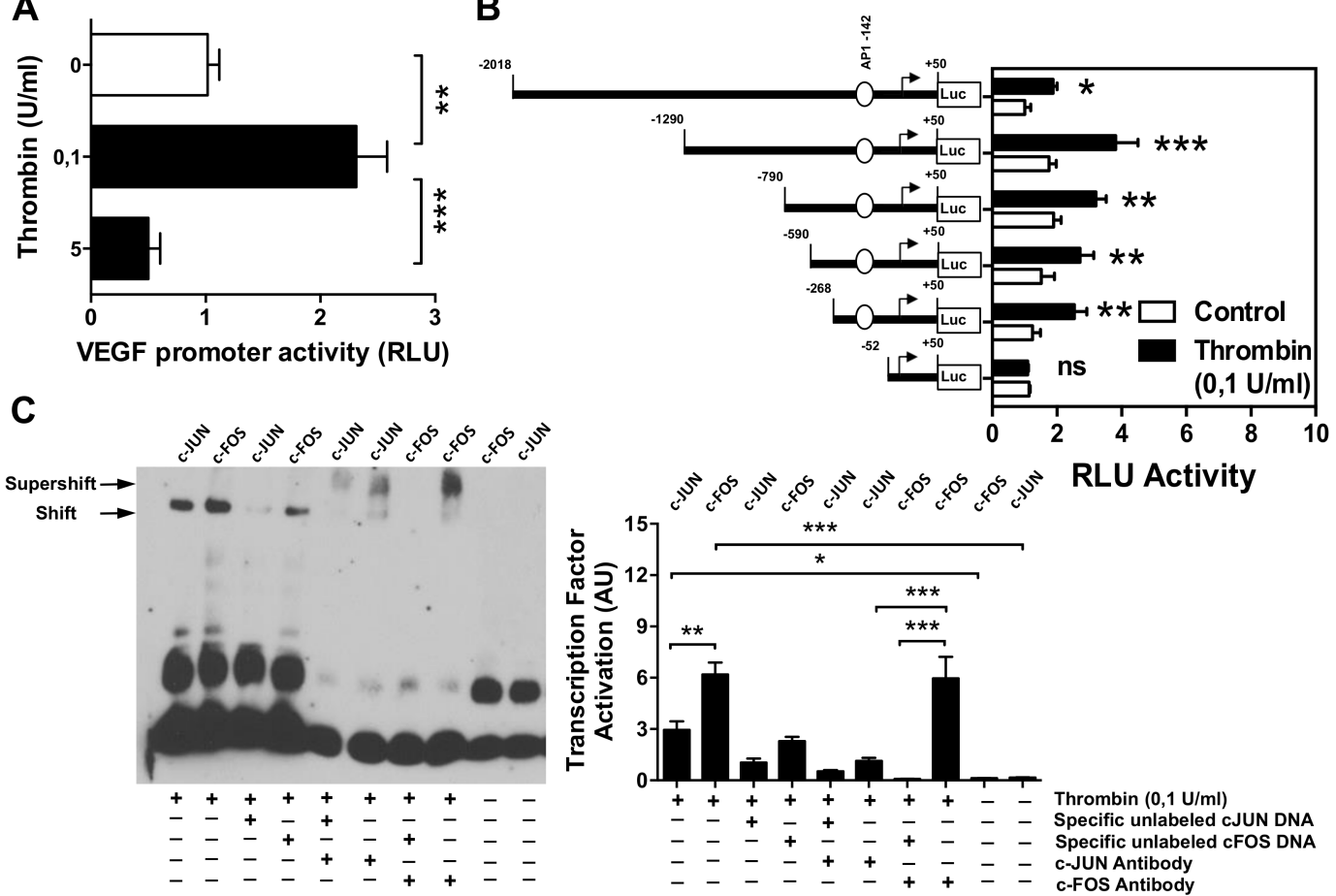

Figure 3. Effect of thrombin stimulation on the VEGF promoter. HMECs were transiently transfected with VEGF promoter constructs, stimulated with thrombin $(0.1 \mathrm{U} / \mathrm{mL})$ for $6 \mathrm{~h}$ (and $12 \mathrm{~h}$, Figure S1B), and analyzed for luciferase activity. (A) Full-length VEGF promoter activity $(n=5)$. (B) Effect of progressive 5 ' deletions of the VEGF promoter on its activity upon stimulation with thrombin $(n=8)$. (C) EMSA identifying the role of c-FOS and c-JUN in mediating VEGF promoter induction by thrombin $(n=4)$. Nuclear extracts were obtained from HMECs treated with thrombin $(0.1 \mathrm{U} / \mathrm{mL})$ for $6 \mathrm{~h}$, and EMSA was performed using c-FOS and c-JUN consensus oligonucleotide probes either in the presence of an excess of specific unlabeled c-FOS or c-JUN DNA, or in the presence of c-FOS or c-JUN-specific antibodies, with quantification of shift- or supershift lanes, respectively. ANOVA mean $+/-\mathrm{SEM}$ with ${ }^{*} p<0.05,{ }^{* *} p<0.01$, and ${ }^{* * *} p<0.001$. 


\subsection{AP-1 Transcription Factor Mediates Thrombin-Induced EC Angiogenesis}

Exposure of HMECs to thrombin resulted in a rapid increase in the FOS and JUN mRNA level ( $p<0.05$; Figure 4A,B), which was approximately 3-fold stronger for FOS, and followed by an upregulation of c-FOS and c-JUN protein $(p<0.05$; Figure $4 \mathrm{C}-\mathrm{D})$, which was 2-fold stronger for c-FOS than c-JUN. Since both proteins-c-JUN and c-FOScombine to form the AP-1 transcription factor complex, we assessed the effect of SR-11302, a specific AP-1 inhibitor. In HMECs pretreated with SR-11302, both the release of VEGF $(p<0.001$ and $p<0.05$; Figure $4 \mathrm{E})$ and the formation of tubes in response to thrombin $(p<0.01$ and $p<0.05$; Figure $4 \mathrm{~F})$ were almost reduced to basal levels, with some residual VEGF release remaining, thus indicating that VEGF release is not entirely controlled by the AP-1 transcription factor complex. To verify if the concentration of the AP-1 blocking agent was optimal, we conducted a prior titration experiment, which revealed that the best blocking effect was achieved with $5 \mathrm{uM} \mathrm{AP-1}$ blocker (Figure S1C).

A

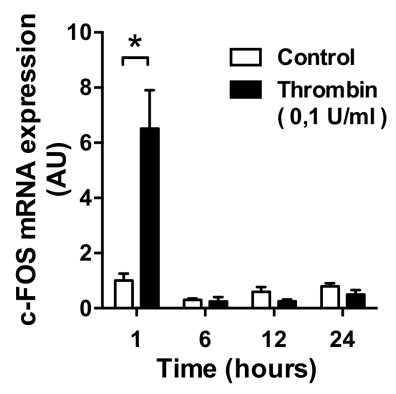

B

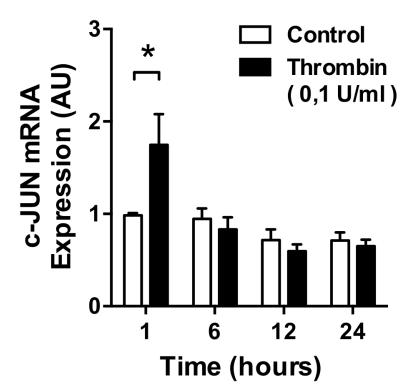

C

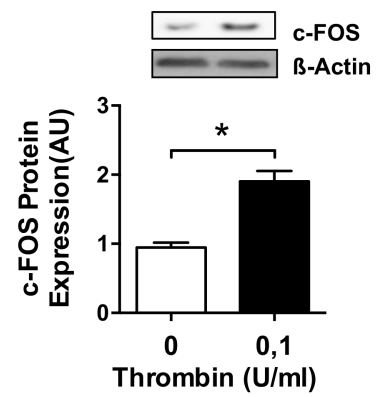

D

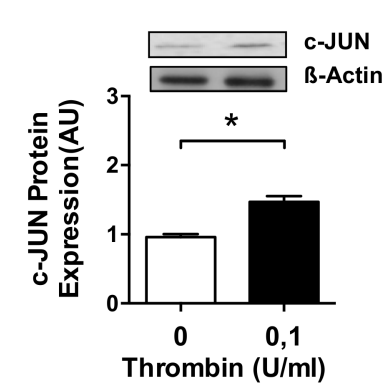

E

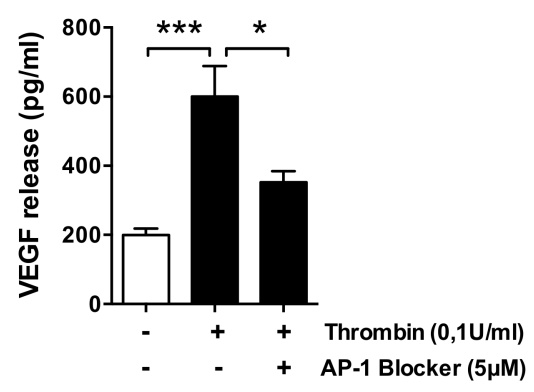

$\mathbf{F}$

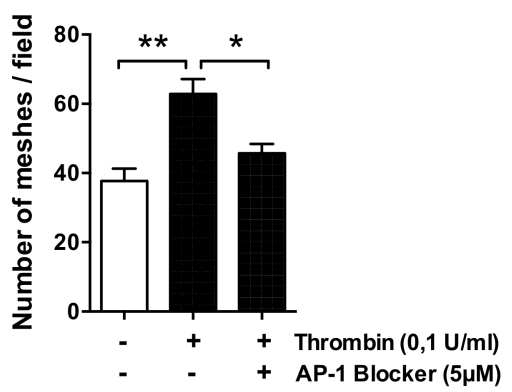

Figure 4. Engagement of AP-1/c-FOS/c-JUN signaling in thrombin-stimulated microvascular ECs. (A-C) HMECs were treated with thrombin $(0.1 \mathrm{U} / \mathrm{mL})$ for the times indicated and assessed for: $(\mathbf{A}, \mathbf{B}) c-F O S$ and c-JUN mRNA level $(n=4)$; $(\mathbf{C}, \mathbf{D}) \mathrm{c}-\mathrm{FOS}$ and c-JUN protein upregulation after $3 \mathrm{~h}$ of stimulation $(n=4)$; (E,F) HMECs were preincubated for $1 \mathrm{~h}$ with or without the AP-1 inhibitor SR-11302 $(5 \mu \mathrm{M})$ and then stimulated with thrombin $(0.1 \mathrm{U} / \mathrm{mL})$ for $24 \mathrm{~h}$, followed by the measurement of (E) VEGF protein release $(n=7-8)$ and $(\mathbf{F})$ the number of endothelial network meshes formed per field $(n=6)$. ANOVA mean $+/-$ SEM with $* p<0.05,{ }^{* *} p<0.01$, and ${ }^{* * *} p<0.001$.

\subsection{ERK Blockade Impairs Thrombin-Induced VEGF Expression by ECs}

Since the extracellular signal-regulated kinase 1/2 (ERK1/2) pathway has been previously linked to signaling from thrombin receptors, we analyzed whether thrombin affects the expression of phosphorylated ERK1/2 (pERK1/2) proteins in HMECs. Indeed, exposure of ECs to thrombin at a dose of $0.1 \mathrm{U} / \mathrm{mL}$ resulted in a strong 4.5-fold increase in pERK1/2 $(p<0.05$; Figure 5A). Importantly, this effect was almost entirely abolished by preincubation of the HMECs with increasing concentrations of lepirudin (Refludan) $(p<0.05)$, a direct thrombin inhibitor. In addition, PD-184352, a specific ERK1/2 inhibitor, dose-dependently reduced the levels of both VEGF mRNA $(p<0.05$ and $p<0.01$; Figure 5B) and also FOS and JUN mRNA ( $p<0.05$ and $p<0.01$; Figure 5 C,D). 

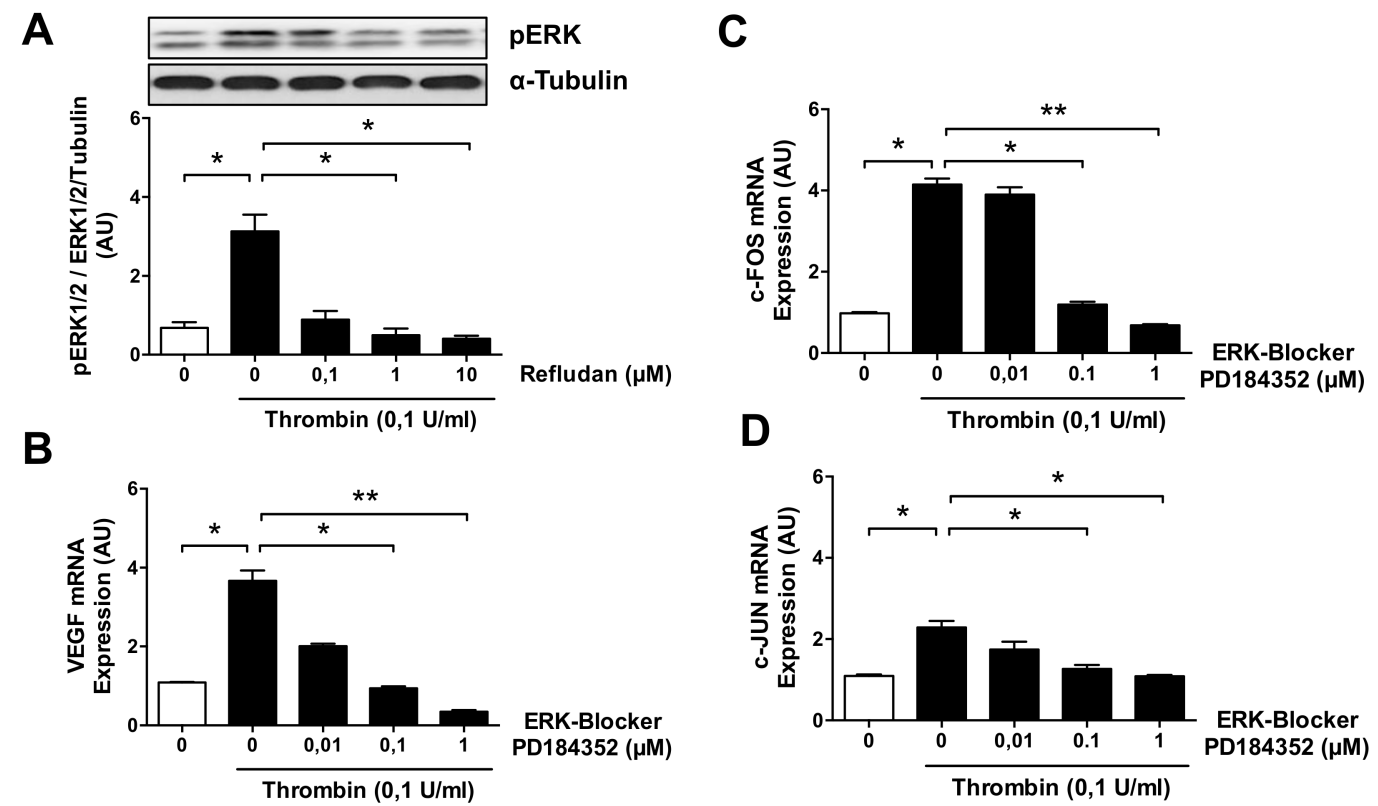

Figure 5. ERK1/2 and AP-1/c-FOS/c-JUN mediate thrombin stimulation in microvascular ECs. (A) HMECs were pretreated for $1 \mathrm{~h}$ with or without the thrombin inhibitor Refludan and then stimulated with thrombin $(0.1 \mathrm{U} / \mathrm{mL})$ for $15 \mathrm{~min}$ and assessed for the presence of phosphorylated ERK1/2 $(n=5)$. (B-D) HMECs were pretreated for $1 \mathrm{~h}$ with or without the ERK inhibitor PD-184352 and then stimulated with thrombin $(0.1 \mathrm{U} / \mathrm{mL})$ for $1 \mathrm{~h}$, after which the levels of (B) VEGF mRNA and (C) FOS mRNA and (D) JUN mRNA were measured $(n=4)$. ANOVA mean $+/-$ SEM with ${ }^{*} p<0.05$ and ${ }^{* *} p<0.01$.

\subsection{Thrombin-Induced PAR-1 Activation Modulates VEGF Expression by ECs}

Next, we studied changes in the cell surface expression of the PAR-1 receptor. The rate of PAR-1 receptor internalization in unstimulated control HMECs was less than $20 \%$ of the total PAR-1 expression (Figure 6A). In contrast, exposure of HMECs to thrombin $(0.1 \mathrm{U} / \mathrm{mL})$ resulted in rapid PAR-1 internalization, which reached $>90 \%$ within $15 \mathrm{~min}$ and persisted at this level during $60 \mathrm{~min}$ of observation (both $p<0.001$ ). Again, this effect was completely eliminated by the thrombin inhibitor Lepirudin / Refludan, and this was already evident at the lowest dose of Refludan tested ( $p<0.001$; Figure $6 \mathrm{~B}$ ). The functional role of PAR-1 for thrombin-induced VEGF production was confirmed by exposing HMECs to the PAR-1 inhibitor BMS200261. Under these conditions, the strong-more than 2-fold-induction of VEGF protein release by thrombin $(p<0.001)$ was reduced in a dose-dependent manner to the level seen in unstimulated control cells $(p<0.05$ and $p<0.01$; Figure $6 \mathrm{C})$. 
A

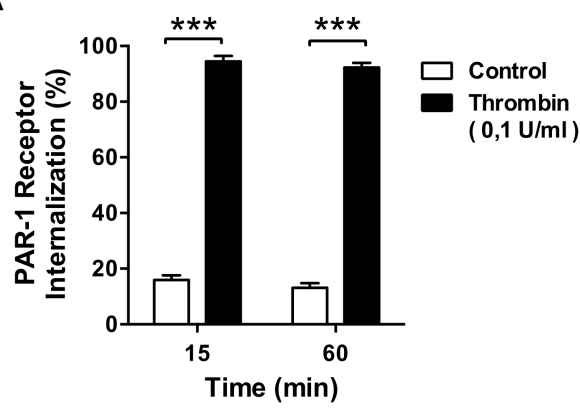

B

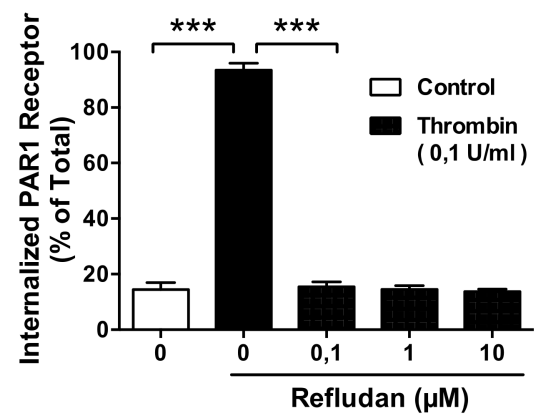

PAR1 Expression and Internalization Upon Thrombin Stimulation

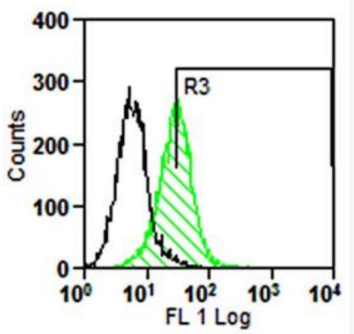

Green Histogram

without Thrombin

Black Histogram

with Thrombin

$(0,1 \mathrm{U} / \mathrm{ml})$
C

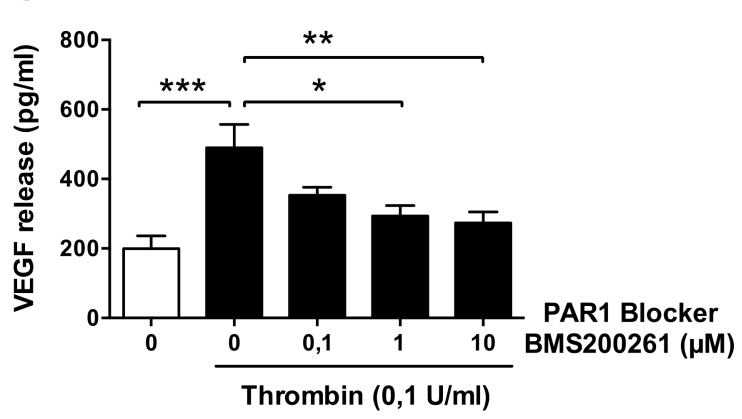

Figure 6. Effect of thrombin on PAR1 receptor in microvascular ECs. (A) Percent internalization of activated (cleaved) PAR-1 receptor by HMECs stimulated with or without thrombin $(0.1 \mathrm{U} / \mathrm{mL})$ for up to $60 \mathrm{~min}(n=4)$ with a representative histogram of PAR-1 expression/internalization on HMECs labeled with SPAN12 antibody, stimulated for 15 min with (black) or without (green) thrombin $(0.1 \mathrm{U} / \mathrm{mL})$. (B) Expression of PAR-1 receptor by HMECs pretreated for $1 \mathrm{~h}$ with or without the thrombin inhibitor Refludan and stimulated with thrombin $(0.1 \mathrm{U} / \mathrm{mL})$ for $15 \mathrm{~min}(n=4)$. (C) VEGF release in response to thrombin $(0.1 \mathrm{pg} / \mathrm{mL})$ by HMECs incubated in the presence of a PAR1 inhibitor, BMS200261, for $24 \mathrm{~h}, n=10$. ANOVA mean $+/-$ SEM with * $p<0.05,{ }^{* *} p<0.01$, and ${ }^{* * *} p<0.001$.

\section{Discussion}

Although the ability of thrombin to modulate the function of ECs is recognized [11], the complexity of thrombin-induced responses is still puzzling. Here, we have unraveled a part of a thrombin-signaling network by demonstrating that c-FOS is a key transcription factor controlling thrombin-induced endothelial VEGF synthesis/angiogenesis, which is in line with earlier implications of its role in angiogenesis [45,52]. This pathway connects the PAR-1 thrombin receptor, the ERK1/2 signaling cascade, and the AP-1 transcription complex.

In this respect, our findings support and extend the previous observations [53] that thrombin at the same concentration $(0.1 \mathrm{U} / \mathrm{mL})$ induced neoangiogenesis in the chick chorioallantoic membrane and that this effect could be blocked by either the VEGF receptor inhibitor or the G-coupled protein receptor inhibitor. Indeed, both human and murine studies have shown that already very low active amounts of thrombin are physiologically active and can trigger clotting $[46,51,54]$. Activation of AP- 1 by thrombin has been observed in ECs and linked to the thrombin-stimulated production of endothelin-1 [55], IL-8 [56], and TF [57].

In addition, AP- 1 has been observed to contribute to VEGF induction in various cell types exposed to a number of different stimuli [45,52,58-70]. However, to the best of our knowledge, the involvement of AP-1 in thrombin-induced VEGF expression in the endothelium has not been reported before. Interestingly, we observed the stimulation of angiogenesis and VEGF expression by thrombin only at a dose of $0.1 \mathrm{U} / \mathrm{mL}$, but not at higher concentrations (1-5 U/mL) reported previously to induce expression of dozens of genes in ECs [11].

Among those genes was FLT1/VEGFR-1, encoding the VEGF receptor, the soluble form of which (sFLT) can act as a competitor for VEGF binding. If the increase in sFLT levels induced by high thrombin was greater than that in VEGF levels, this could lead to 
an attenuated angiogenic response. However, while this could explain the lack of effect of high thrombin concentrations on angiogenesis, the absence of an appreciable effect on $V E G F$ itself is less clear. One may hypothesize that high thrombin concentrations may induce other transcription factors that in turn interact with c-FOS to inhibit its binding to target sequences on the VEGF promoter [37].

Our study did not aim to explain whether the mechanism of angiogenesis mediated by c-FOS and VEGF represents an adaptive or maladaptive response to thrombin, as this likely depends on the pathophysiological context. On the one hand, thrombin-mediated angiogenesis may contribute to the prompt wound healing after injury. On the other hand, it may also drive abnormal angiogenesis in inflammatory pathologies; e.g., it has been observed that proinflammatory cytokines upregulate PAR-1 and that thrombin upregulates VEGF in retinal pigment epithelial cells [71]. Moreover, patients with proliferative diabetic retinopathy display an abundant expression of PAR-1 in the retinal endothelium and have high levels of thrombin and VEGF in the vitreous fluid [71].

Recently, there has been considerable interest in the potential involvement of thrombin and VEGF in COVID-19-induced ARDS. The nature of the coagulopathy and the ARDS associated with COVID-19 is not fully understood to date [39,72,73], but detailed examination of lung specimens from patients who had died from COVID-19 revealed extensive endothelial injury, microthrombosis, and neoangiogenesis [39].

These changes were associated with increased expression of many genes important for angiogenesis, including VEGF. Other studies reported on increased levels of circulating VEGF in COVID-19 [74-76]. The exact contribution of thrombin to increased VEGF expression in COVID-19 is difficult to estimate, since VEGF production may also be driven by ARDS-associated hypoxia or inflammatory cytokines, and the intensity of these stimuli may change over the course of disease [74].

Nevertheless, increasing evidence of endothelial damage and thrombosis in pulmonary vasculature has prompted the idea of including PAR-1 inhibitors in the treatment of COVID-19 [77]. Alternatively, the blockade of VEGF could be considered. In this respect, initial clinical observations from a limited number of patients may suggest that anti-VEGF therapy may indeed be of some benefit for patients with severe COVID-19 [78]. In mice, targeted neutralization of VEGF in the lungs was found to alleviate endotoxin-induced ARDS [79].

\section{Conclusions}

We have previously shown that c-FOS is a key transcription factor in the control of mesothelial angiogenesis in the context of peritoneal dialysis $[45,52]$. The induction of VEGF expression and angiogenic response by ECs in response to thrombin is a central element in vascular repair within the cardiovascular system. We here show that the exposure of HMECs to thrombin engages signaling through the PAR-1-ERK1/2-AP-1 axis to control $V E G F$ transcription and secretion and concomitant VEGF-induced endothelial angiogenesis. The activity of the AP-1 transcription factor complex is regulated in a multifaceted manner [52], among others, through the availability and heterodimerization of members of the FOS and the JUN family. In addition to the constitutive engagement of c-JUN, the adaptive regulation of c-FOS described here mediates a highly dynamic responsiveness of the AP-1 transcription factor complex to environmental cues, such as thrombin, thus allowing ECs to rapidly respond to thromboinflammation. These observations offer a greater understanding of the endothelial response to thromboinflammation, which may help to interpret the results of clinical trials tackling the conditions associated with endothelial cell injury and thrombosis.

Supplementary Materials: The following are available online at https://www.mdpi.com/article/ 10.3390/cells10040910/s1, Figure S1: Supplemental Data, Table S1: Sequences of primers used in quantitative-real-time-PCR analysis, Table S2: Antibodies and reagents used for EMSA and western blot. 
Author Contributions: Conceptualization, R.C., G.M., D.Z. and J.W.; Data curation, R.C., G.M., I.H., M.S., C.L., H.Z., D.W., L.C., J.K.M. and K.K.; Formal analysis, R.C., G.M., I.H., M.S., C.L., H.Z., D.W., L.C., J.K.M., K.K., D.Z. and J.W.; Funding acquisition, R.C. and G.M.; Investigation, R.C., I.H., M.S., C.L., H.Z., D.W., L.C., J.K.M., K.K. and D.Z.; Methodology, R.C., I.H., M.S., C.L., H.Z., D.W., L.C., J.K.M., K.K. and D.Z.; Project administration, R.C.; Software, R.C. and J.K.M.; Supervision, R.C.; Validation, R.C.; Visualization, R.C., G.M., J.K.M. and J.W.; Writing-original draft, R.C., G.M., D.Z. and J.W.; Writing-review \& editing, R.C., G.M., D.Z. and J.W. All authors have read and agreed to the published version of the manuscript.

Funding: G.M.'s contributions were made possible by funding from the German Federal Ministry for Education and Research (BMBF) and German Research Foundation (DFG) through the Berlin Institute of Healthy (BIH) Center for Regenerative Therapies (BCRT) and the Berlin-Brandenburg School for Regenerative Therapies (BSRT, GSC203), respectively, and the European Union's Horizon 2020 Research and Innovation Program under grant agreements Nos. 733006 (PACE) and 779293 (HIPGEN). The study was further supported by DFG through the CRC 1365 (Nephroprotection; project number 394046635, subproject A03 to R.C.).

Institutional Review Board Statement: Not applicable.

Informed Consent Statement: Not applicable.

Data Availability Statement: Not new data.

Conflicts of Interest: All authors declare that they have no conflict of interest and that the results in this paper have not been published previously. The funders had no role in the design of the study; in the collection, analyses, or interpretation of data; in the writing of the manuscript; or in the decision to publish the results.

\section{Abbreviations}

$\begin{array}{ll}\text { ARDS } & \text { Acute respiratory distress syndrome } \\ \text { COVID-19 } & \text { Coronavirus-induced disease 2019 } \\ \text { ECs / HMECs } & \text { Endothelial cells / Human microvascular endothelial cells } \\ \text { AP-1 } & \text { Activator protein 1 transcription factor complex composed of subunits c-FOS and c-JUN } \\ \text { ERK1/2 } & \text { Extracellular signal-regulated kinases } 1 \text { and } 2 \\ \text { PAR-1 } & \text { Protease activated receptor 1, thrombin receptor } \\ \text { TF/CD142 } & \text { Tissue factor, highly procoagulant molecule triggers the TF pathway of coagulation } \\ \text { FI-XII / I-XIIa } & \text { Native and activated coagulation factors I-XII, respectively. } \\ \text { VEGF } & \text { Vascular endothelial growth factor }\end{array}$

\section{References}

1. Collins, D.R.J.; Tompson, A.C.; Onakpoya, I.J.; Roberts, N.; Ward, A.M.; Heneghan, C.J. Global cardiovascular risk assessment in the primary prevention of cardiovascular disease in adults: Systematic review of systematic reviews. BMJ Open 2017, 7, e013650. [CrossRef]

2. Roth, G.A.; Mensah, G.A.; Johnson, C.O.; Addolorato, G.; Ammirati, E.; Baddour, L.M.; Barengo, N.C.; Beaton, A.Z.; Benjamin, E.J.; Benziger, C.P.; et al. Global Burden of Cardiovascular Diseases and Risk Factors, 1990-2019: Update from the GBD 2019 Study. J. Am. Coll. Cardiol. 2020, 76, 2982-3021. [CrossRef]

3. Vanhoutte, P.M.; Shimokawa, H.; Tang, E.H.C.; Feletou, M. Endothelial dysfunction and vascular disease. Acta Physiol. 2009, 196, 193-222. [CrossRef]

4. Yau, J.W.; Teoh, H.; Verma, S. Endothelial cell control of thrombosis. BMC Cardiovasc. Disord. 2015, 15, 130. [CrossRef]

5. Bermejo-Martin, J.F.; Martín-Fernandez, M.; López-Mestanza, C.; Duque, P.; Almansa, R. Shared Features of Endothelial Dysfunction between Sepsis and Its Preceding Risk Factors (Aging and Chronic Disease). J. Clin. Med. 2018, 7, 400. [CrossRef]

6. Terenzi, D.C.; Trac, J.Z.; Teoh, H.; Gerstein, H.C.; Bhatt, D.L.; Al-Omran, M.; Verma, S.; Hess, D.A. Vascular Regenerative Cell Exhaustion in Diabetes: Translational Opportunities to Mitigate Cardiometabolic Risk. Trends Mol. Med. 2019, 25, 640-655. [CrossRef] [PubMed]

7. Morrissey, J.H. Tissue factor: A key molecule in hemostatic and nonhemostatic systems. Int. J. Hematol. 2004, 79, 103-108. [CrossRef] [PubMed]

8. Moll, G.; Ankrum, J.A.; Kamhieh-Milz, J.; Bieback, K.; Ringden, O.; Volk, H.D.; Geissler, S.; Reinke, P. Intravascular Mesenchymal Stromal/Stem Cell Therapy Product Diversification: Time for New Clinical Guidelines. Trends Mol. Med. 2019, 25, 149-163. [CrossRef] [PubMed] 
9. Moll, G.; Drzeniek, N.; Kamhieh-Milz, J.; Geissler, S.; Volk, H.-D.; Reinke, P. MSC Therapies for COVID-19: Importance of Patient Coagulopathy, Thromboprophylaxis, Cell Product Quality and Mode of Delivery for Treatment Safety and Efficacy. Front. Immunol. 2020, 11, 1091. [CrossRef]

10. Van Hinsbergh, V.W.M. Endothelium-Role in regulation of coagulation and inflammation. Semin. Immunopathol. 2012, 34, 93-106. [CrossRef] [PubMed]

11. Minami, T.; Sugiyama, A.; Wu, S.-Q.; Abid, R.; Kodama, T.; Aird, W.C. Thrombin and Phenotypic Modulation of the Endothelium. Arterioscler. Thromb. Vasc. Biol. 2004, 24, 41-53. [CrossRef] [PubMed]

12. Petrlova, J.; Petruk, G.; Huber, R.G.; McBurnie, E.W.; van der Plas, M.J.A.; Bond, P.J.; Puthia, M.; Schmidtchen, A. Thrombinderived C-terminal fragments aggregate and scavenge bacteria and their proinflammatory products. J. Biol. Chem. 2020, 295, 3417-3430. [CrossRef] [PubMed]

13. Saravanan, R.; Choong, Y.K.; Lim, C.H.; Lim, L.M.; Petrlova, J.; Schmidtchen, A. Cell-Free DNA Promotes Thrombin Autolysis and Generation of Thrombin-Derived C-Terminal Fragments. Front. Immunol. 2021, 12. [CrossRef]

14. Maragoudakis, M.E.; Tsopanoglou, N.E.; Andriopoulou, P. Mechanism of thrombin-induced angiogenesis. Biochem. Soc. Trans. 2002, 30, 173-177. [CrossRef]

15. Herbert, J.M.; Dupuy, E.; Laplace, M.C.; Zini, J.M.; Bar Shavit, R.; Tobelem, G. Thrombin induces endothelial cell growth via both a proteolytic and a non-proteolytic pathway. Biochem. J. 1994, 303 Pt 1, 227-231. [CrossRef]

16. Tsopanoglou, N.E.; Maragoudakis, M.E. Thrombin's central role in angiogenesis and pathophysiological processes. Eur. Cytokine Netw. 2009, 20, 171-179. [CrossRef] [PubMed]

17. Qadura, M.; Terenzi, D.C.; Verma, S.; Al-Omran, M.; Hess, D.A. Concise Review: Cell Therapy for Critical Limb Ischemia: An Integrated Review of Preclinical and Clinical Studies. Stem Cells 2018, 36, 161-171. [CrossRef] [PubMed]

18. Tsopanoglou, N.E.; Andriopoulou, P.; Maragoudakis, M.E. On the mechanism of thrombin-induced angiogenesis: Involvement of alphavbeta3-integrin. Am. J. Physiol. Cell Physiol. 2002, 283, C1501-C1510. [CrossRef]

19. Haralabopoulos, G.C.; Grant, D.S.; Kleinman, H.K.; Maragoudakis, M.E. Thrombin promotes endothelial cell alignment in Matrigel in vitro and angiogenesis in vivo. Am. J. Physiol. 1997, 273, C239-C245. [CrossRef]

20. Tsopanoglou, N.E.; Maragoudakis, M.E. On the mechanism of thrombin-induced angiogenesis. Potentiation of vascular endothelial growth factor activity on endothelial cells by up-regulation of its receptors. J. Biol. Chem. 1999, 274, 23969-23976. [CrossRef]

21. Wang, J.; Morita, I.; Onodera, M.; Murota, S.I. Induction of KDR expression in bovine arterial endothelial cells by thrombin: Involvement of nitric oxide. J. Cell Physiol. 2002, 190, 238-250. [CrossRef]

22. Huang, Y.Q.; Li, J.J.; Hu, L.; Lee, M.; Karpatkin, S. Thrombin induces increased expression and secretion of VEGF from human FS4 fibroblasts, DU145 prostate cells and CHRF megakaryocytes. Thromb. Haemost. 2001, 86, 1094-1098.

23. Möhle, R.; Green, D.; Moore, M.A.; Nachman, R.L.; Rafii, S. Constitutive production and thrombin-induced release of vascular endothelial growth factor by human megakaryocytes and platelets. Proc. Natl. Acad. Sci. USA 1997, 94, 663-668. [CrossRef]

24. $\mathrm{Hu}, \mathrm{S}$.; Wu, G.; Zheng, J.; Liu, X.; Zhang, Y. Astrocytic thrombin-evoked VEGF release is dependent on p44/42 MAPKs and PAR1. Biochem. Biophys. Res. Commun. 2019, 509, 585-589. [CrossRef]

25. Bian, Z.M.; Elner, S.G.; Elner, V.M. Thrombin-induced VEGF expression in human retinal pigment epithelial cells. Investig. Ophthalmol. Vis. Sci. 2007, 48, 2738-2746. [CrossRef] [PubMed]

26. Terasaki, H.; Shirasawa, M.; Otsuka, H.; Yamashita, T.; Uchino, E.; Hisatomi, T.; Sonoda, S.; Sakamoto, T. Different Effects of Thrombin on VEGF Secretion, Proliferation, and Permeability in Polarized and Non-polarized Retinal Pigment Epithelial Cells. Curr. Eye Res. 2015, 40, 936-945. [CrossRef] [PubMed]

27. Hollborn, M.; Petto, C.; Steffen, A.; Trettner, S.; Bendig, A.; Wiedemann, P.; Bringmann, A.; Kohen, L. Effects of thrombin on RPE cells are mediated by transactivation of growth factor receptors. Investig. Ophthalmol. Vis. Sci. 2009, 50, 4452-4459. [CrossRef] [PubMed]

28. Arisato, T.; Sarker, K.P.; Kawahara, K.; Nakata, M.; Hashiguchi, T.; Osame, M.; Kitajima, I.; Maruyama, I. The agonist of the protease-activated receptor-1 (PAR) but not PAR3 mimics thrombin-induced vascular endothelial growth factor release in human smooth muscle cells. Cell. Mol. Life Sci. 2003, 60, 1716-1724. [CrossRef] [PubMed]

29. Bassus, S.; Herkert, O.; Kronemann, N.; Görlach, A.; Bremerich, D.; Kirchmaier, C.M.; Busse, R.; Schini-Kerth, V.B. Thrombin causes vascular endothelial growth factor expression in vascular smooth muscle cells: Role of reactive oxygen species. Arterioscler. Thromb. Vasc. Biol. 2001, 21, 1550-1555. [CrossRef]

30. Strande, J.L.; Phillips, S.A. Thrombin increases inflammatory cytokine and angiogenic growth factor secretion in human adipose cells in vitro. J. Inflamm. 2009, 6, 4. [CrossRef] [PubMed]

31. Belling, F.; Ribeiro, A.; Wörnle, M.; Ladurner, R.; Mussack, T.; Sitter, T.; Sauter, M. PAR-1 mediates the thrombin-induced mesothelial cell overproduction of VEGF and PAI-1. Int. J. Artif. Organs 2013, 36, 97-104. [CrossRef] [PubMed]

32. Sarker, K.P.; Yamahata, H.; Nakata, M.; Arisato, T.; Nakajima, T.; Kitajima, I.; Maruyama, I. Recombinant thrombomodulin inhibits thrombin-induced vascular endothelial growth factor production in neuronal cells. Haemostasis 1999, 29, 343-352. [CrossRef] [PubMed]

33. Yamahata, H.; Takeshima, H.; Kuratsu, J.; Sarker, K.P.; Tanioka, K.; Wakimaru, N.; Nakata, M.; Kitajima, I.; Maruyama, I. The role of thrombin in the neo-vascularization of malignant gliomas: An intrinsic modulator for the up-regulation of vascular endothelial growth factor. Int. J. Oncol. 2002, 20, 921-928. [CrossRef] [PubMed] 
34. Sarker, K.P.; Biswas, K.K.; Yamaji, K.; Yamakuchi, M.; Hashiguchi, T.; Lee, K.Y.; Maruyama, I. Inhibition of thrombin-induced vascular endothelial growth factor production in human neuroblastoma (NB-1) cells by argatroban. Pathophysiol. Haemost. Thromb. 2005, 34, 41-47. [CrossRef] [PubMed]

35. Liu, J.; Schuff-Werner, P.; Steiner, M. Thrombin/thrombin receptor (PAR-1)-mediated induction of IL-8 and VEGF expression in prostate cancer cells. Biochem. Biophys. Res. Commun. 2006, 343, 183-189. [CrossRef] [PubMed]

36. Dupuy, E.; Habib, A.; Lebret, M.; Yang, R.; Levy-Toledano, S.; Tobelem, G. Thrombin induces angiogenesis and vascular endothelial growth factor expression in human endothelial cells: Possible relevance to HIF-1 $\alpha$. J. Thromb. Haemost. JTH 2003, 1, 1096-1102. [CrossRef]

37. Pagès, G.; Pouysségur, J. Transcriptional regulation of the Vascular Endothelial Growth Factor gene-A concert of activating factors. Cardiovasc. Res. 2005, 65, 564-573. [CrossRef]

38. Colling, M.E.; Kanthi, Y. COVID-19-associated coagulopathy: An exploration of mechanisms. Vasc. Med. 2020, 25, 471-478. [CrossRef] [PubMed]

39. Ackermann, M.; Verleden, S.E.; Kuehnel, M.; Haverich, A.; Welte, T.; Laenger, F.; Vanstapel, A.; Werlein, C.; Stark, H.; Tzankov, A.; et al. Pulmonary Vascular Endothelialitis, Thrombosis, and Angiogenesis in Covid-19. N. Engl. J. Med. 2020, 383, 120-128. [CrossRef]

40. Nagy, J.A.; Dvorak, A.M.; Dvorak, H.F. VEGF-A and the induction of pathological angiogenesis. Annu. Rev. Pathol. 2007, 2, 251-275. [CrossRef]

41. Barratt, S.; Medford, A.R.; Millar, A.B. Vascular endothelial growth factor in acute lung injury and acute respiratory distress syndrome. Respir. Int. Rev. Thorac. Dis. 2014, 87, 329-342. [CrossRef] [PubMed]

42. Catar, R.; Witowski, J.; Zhu, N.; Lucht, C.; Derrac Soria, A.; Uceda Fernandez, J.; Chen, L.; Jones, S.A.; Fielding, C.A.; Rudolf, A.; et al. IL-6 Trans-Signaling Links Inflammation with Angiogenesis in the Peritoneal Membrane. J. Am. Soc. Nephrol. 2017, 28, 1188-1199. [CrossRef] [PubMed]

43. Andrzejewska, A.; Catar, R.; Schoon, J.; Qazi, T.H.; Sass, F.A.; Jacobi, D.; Blankenstein, A.; Reinke, S.; Kruger, D.; Streitz, M.; et al. Multi-Parameter Analysis of Biobanked Human Bone Marrow Stromal Cells Shows Little Influence for Donor Age and Mild Comorbidities on Phenotypic and Functional Properties. Front. Immunol. 2019, 10, 2474. [CrossRef]

44. Korybalska, K.; Pyda, M.; Kawka, E.; Grajek, S.; Bręborowicz, A.; Witowski, J. Interpretation of elevated serum VEGF concentrations in patients with myocardial infarction. Cytokine 2011, 54, 74-78. [CrossRef]

45. Catar, R.; Witowski, J.; Wagner, P.; Annett Schramm, I.; Kawka, E.; Philippe, A.; Dragun, D.; Jorres, A. The proto-oncogene c-Fos transcriptionally regulates VEGF production during peritoneal inflammation. Kidney Int. 2013, 84, 1119-1128. [CrossRef]

46. Moll, G.; Rasmusson-Duprez, I.; von Bahr, L.; Connolly-Andersen, A.M.; Elgue, G.; Funke, L.; Hamad, O.A.; Lonnies, H.; Magnusson, P.U.; Sanchez, J.; et al. Are therapeutic human mesenchymal stromal cells compatible with human blood? Stem Cells 2012, 30, 1565-1574. [CrossRef]

47. Moll, G.; Alm, J.J.; Davies, L.C.; von Bahr, L.; Heldring, N.; Stenbeck-Funke, L.; Hamad, O.A.; Hinsch, R.; Ignatowicz, L.; Locke, M.; et al. Do cryopreserved mesenchymal stromal cells display impaired immunomodulatory and therapeutic properties? Stem Cells 2014, 32, 2430-2442. [CrossRef]

48. Zickler, D.; Luecht, C.; Willy, K.; Chen, L.; Witowski, J.; Girndt, M.; Fiedler, R.; Storr, M.; Kamhieh-Milz, J.; Schoon, J.; et al. Tumour necrosis factor-alpha in uraemic serum promotes osteoblastic transition and calcification of vascular smooth muscle cells via extracellular signal-regulated kinases and activator protein 1/c-FOS-mediated induction of interleukin 6 expression. Nephrol. Dial. Transplant. Off. Publ. Eur. Dial. Transpl. Assoc. Eur. Ren. Assoc. 2018, 33, 574-585. [CrossRef]

49. Finkenzeller, G.; Sparacio, A.; Technau, A.; Marmé, D.; Siemeister, G. Sp1 recognition sites in the proximal promoter of the human vascular endothelial growth factor gene are essential for platelet-derived growth factor-induced gene expression. Oncogene 1997, 15, 669-676. [CrossRef]

50. Brass, L.F.; Pizarro, S.; Ahuja, M.; Belmonte, E.; Blanchard, N.; Stadel, J.M.; Hoxie, J.A. Changes in the structure and function of the human thrombin receptor during receptor activation, internalization, and recycling. J. Biol. Chem. 1994, 269, $2943-2952$. [CrossRef]

51. Sadeghi, B.; Moretti, G.; Arnberg, F.; Samen, E.; Kohein, B.; Catar, R.; Kamhieh-Milz, J.; Geissler, S.; Moll, G.; Holmin, S.; et al. Preclinical Toxicity Evaluation of Clinical Grade Placenta-Derived Decidua Stromal Cells. Front. Immunol. 2019, 10, 2685. [CrossRef]

52. Bonder, C.S.; Ebert, L.M. Fos-icking for control of angiogenesis: Increasing the longevity of peritoneal dialysis. Kidney Int. 2013, 84, 1065-1067. [CrossRef]

53. Caunt, M.; Huang, Y.Q.; Brooks, P.C.; Karpatkin, S. Thrombin induces neoangiogenesis in the chick chorioallantoic membrane. J. Thromb. Haemost. 2003, 1, 2097-2102. [CrossRef]

54. Moll, G.; Ignatowicz, L.; Catar, R.; Luecht, C.; Sadeghi, B.; Hamad, O.; Jungebluth, P.; Dragun, D.; Schmidtchen, A.; Ringden, O. Different Procoagulant Activity of Therapeutic Mesenchymal Stromal Cells Derived from Bone Marrow and Placental Decidua. Stem Cells Dev. 2015, 24, 2269-2279. [CrossRef]

55. Delerive, P.; Martin-Nizard, F.; Chinetti, G.; Trottein, F.; Fruchart, J.C.; Najib, J.; Duriez, P.; Staels, B. Peroxisome proliferatoractivated receptor activators inhibit thrombin-induced endothelin-1 production in human vascular endothelial cells by inhibiting the activator protein-1 signaling pathway. Circ. Res. 1999, 85, 394-402. [CrossRef] 
56. Takata, M.; Urakaze, M.; Temaru, R.; Yamazaki, K.; Nakamura, N.; Nobata, Y.; Kishida, M.; Sato, A.; Kobayashi, M. Pravastatin suppresses the interleukin-8 production induced by thrombin in human aortic endothelial cells cultured with high glucose by inhibiting the p44/42 mitogen activated protein kinase. Br. J. Pharmacol. 2001, 134, 753-762. [CrossRef]

57. Pendurthi, U.R.; Williams, J.T.; Rao, L.V. Inhibition of tissue factor gene activation in cultured endothelial cells by curcumin. Suppression of activation of transcription factors Egr-1, AP-1, and NF-kB. Arterioscler. Thromb. Vasc. Biol. 1997, 17, $3406-3413$. [CrossRef]

58. Heo, K.; Park, K.A.; Kim, Y.H.; Kim, S.H.; Oh, Y.S.; Kim, I.H.; Ryu, S.H.; Suh, P.G. Sphingosine 1-phosphate induces vascular endothelial growth factor expression in endothelial cells. BMB Rep. 2009, 42, 685-690. [CrossRef]

59. Yin, Y.; Wang, S.; Sun, Y.; Matt, Y.; Colburn, N.H.; Shu, Y.; Han, X. JNK/AP-1 pathway is involved in tumor necrosis factor-alpha induced expression of vascular endothelial growth factor in MCF7 cells. Biomed. Pharmacother. 2009, 63, 429-435. [CrossRef] [PubMed]

60. Kleiner, J.; Hollborn, M.; Wiedemann, P.; Bringmann, A. Activator protein-1 contributes to the NaCl-induced expression of VEGF and PlGF in RPE cells. Mol. Vis. 2018, 24, 647-666.

61. Lee, C.C.; Chen, S.C.; Tsai, S.C.; Wang, B.W.; Liu, Y.C.; Lee, H.M.; Shyu, K.G. Hyperbaric oxygen induces VEGF expression through ERK, JNK and c-Jun/AP-1 activation in human umbilical vein endothelial cells. J. Biomed. Sci. 2006, 13, 143-156. [CrossRef]

62. Bancroft, C.C.; Chen, Z.; Yeh, J.; Sunwoo, J.B.; Yeh, N.T.; Jackson, S.; Jackson, C.; Van Waes, C. Effects of pharmacologic antagonists of epidermal growth factor receptor, PI3K and MEK signal kinases on NF-kappaB and AP-1 activation and IL-8 and VEGF expression in human head and neck squamous cell carcinoma lines. Int. J. Cancer 2002, 99, 538-548. [CrossRef]

63. Cho, M.L.; Jung, Y.O.; Moon, Y.M.; Min, S.Y.; Yoon, C.H.; Lee, S.H.; Park, S.H.; Cho, C.S.; Jue, D.M.; Kim, H.Y. Interleukin18 induces the production of vascular endothelial growth factor (VEGF) in rheumatoid arthritis synovial fibroblasts via AP-1dependent pathways. Immunol. Lett. 2006, 103, 159-166. [CrossRef]

64. Chang, H.J.; Park, J.S.; Kim, M.H.; Hong, M.H.; Kim, K.M.; Kim, S.M.; Shin, B.A.; Ahn, B.W.; Jung, Y.D. Extracellular signalregulated kinases and AP-1 mediate the up-regulation of vascular endothelial growth factor by PDGF in human vascular smooth muscle cells. Int. J. Oncol. 2006, 28, 135-141. [CrossRef]

65. Yu, H.S.; Wang, S.W.; Chang, A.C.; Tai, H.C.; Yeh, H.I.; Lin, Y.M.; Tang, C.H. Bradykinin promotes vascular endothelial growth factor expression and increases angiogenesis in human prostate cancer cells. Biochem. Pharmacol. 2014, 87, 243-253. [CrossRef]

66. Hossain, M.A.; Bouton, C.M.; Pevsner, J.; Laterra, J. Induction of vascular endothelial growth factor in human astrocytes by lead. Involvement of a protein kinase C/activator protein-1 complex-dependent and hypoxia-inducible factor 1-independent signaling pathway. J. Biol. Chem. 2000, 275, 27874-27882. [CrossRef] [PubMed]

67. Urata, Y.; Yamaguchi, M.; Higashiyama, Y.; Ihara, Y.; Goto, S.; Kuwano, M.; Horiuchi, S.; Sumikawa, K.; Kondo, T. Reactive oxygen species accelerate production of vascular endothelial growth factor by advanced glycation end products in RAW264.7 mouse macrophages. Free Radic. Biol. Med. 2002, 32, 688-701. [CrossRef]

68. Fujita, M.; Hayashi, I.; Yamashina, S.; Fukamizu, A.; Itoman, M.; Majima, M. Angiotensin type 1a receptor signaling-dependent induction of vascular endothelial growth factor in stroma is relevant to tumor-associated angiogenesis and tumor growth. Carcinogenesis 2005, 26, 271-279. [CrossRef] [PubMed]

69. Itaya, H.; Imaizumi, T.; Yoshida, H.; Koyama, M.; Suzuki, S.; Satoh, K. Expression of vascular endothelial growth factor in human monocyte/macrophages stimulated with lipopolysaccharide. Thromb. Haemost. 2001, 85, 171-176. [CrossRef] [PubMed]

70. Textor, B.; Sator-Schmitt, M.; Richter, K.H.; Angel, P.; Schorpp-Kistner, M. c-Jun and JunB are essential for hypoglycemia-mediated VEGF induction. Ann. N. Y. Acad. Sci. 2006, 1091, 310-318. [CrossRef] [PubMed]

71. Abu El-Asrar, A.M.; Alam, K.; Nawaz, M.I.; Mohammad, G.; Van den Eynde, K.; Siddiquei, M.M.; Mousa, A.; De Hertogh, G.; Opdenakker, G. Upregulation of Thrombin/Matrix Metalloproteinase-1/Protease-Activated Receptor-1 Chain in Proliferative Diabetic Retinopathy. Curr. Eye Res. 2016, 41, 1590-1600. [CrossRef]

72. Hariri, L.; Hardin, C.C. Covid-19, Angiogenesis, and ARDS Endotypes. N. Engl. J. Med. 2020, 383, 182-183. [CrossRef] [PubMed]

73. Libby, P.; Luscher, T. COVID-19 is, in the end, an endothelial disease. Eur. Heart J. 2020, 41, 3038-3044. [CrossRef] [PubMed]

74. Pine, A.B.; Meizlish, M.L.; Goshua, G.; Chang, C.H.; Zhang, H.; Bishai, J.; Bahel, P.; Patel, A.; Gbyli, R.; Kwan, J.M.; et al. Circulating markers of angiogenesis and endotheliopathy in COVID-19. Pulm. Circ. 2020, 10, 2045894020966547. [CrossRef] [PubMed]

75. Vassiliou, A.G.; Keskinidou, C.; Jahaj, E.; Gallos, P.; Dimopoulou, I.; Kotanidou, A.; Orfanos, S.E. ICU Admission Levels of Endothelial Biomarkers as Predictors of Mortality in Critically Ill COVID-19 Patients. Cells 2021, 10, 186. [CrossRef] [PubMed]

76. Rovas, A.; Osiaevi, I.; Buscher, K.; Sackarnd, J.; Tepasse, P.R.; Fobker, M.; Kühn, J.; Braune, S.; Göbel, U.; Thölking, G.; et al. Microvascular dysfunction in COVID-19: The MYSTIC study. Angiogenesis 2021, 24, 145-157. [CrossRef]

77. Sriram, K.; Insel, P.A. Proteinase-activated receptor 1: A target for repurposing in the treatment of COVID-19? Br. J. Pharmacol. 2020, 177, 4971-4974. [CrossRef]

78. Pang, J.; Xu, F.; Aondio, G.; Li, Y.; Fumagalli, A.; Lu, M.; Valmadre, G.; Wei, J.; Bian, Y.; Canesi, M.; et al. Efficacy and tolerability of bevacizumab in patients with severe Covid-19. Nat. Commun. 2021, 12, 814. [CrossRef]

79. Zhang, Z.; Lu, D.S.; Zhang, D.Q.; Wang, X.; Ming, Y.; Wu, Z.Y. Targeted Antagonism of Vascular Endothelial Growth Factor Reduces Mortality of Mice with Acute Respiratory Distress Syndrome. Curr. Med. Sci. 2020, 40, 671-676. [CrossRef] 